\title{
УАК 640.43
}

Г.M.Тарасюк,

д.е.н., професор, декан факультету бізнесу та сфери обслуговуваннл, Аержавний університет " Житомирська політехніка"

ORCID ID: 0000-0001-5112-102X

A.O. Чazaйдa,

к. т.н., дочент, дочент кафедри туризму та готельно-ресторанної справи, Аержавний університет " Житомирсъка політехніка"

ORCID ID: 000-0003-1826-9545

I. О. Петровсъка,

к.е.н., дочент, старший науковий співробітник, завідувач кафедри індустрії гостинності та сталого розвитку, Таврійсъкий національний університет імені В. І. Вернадсъкого

ORCID ID: 0000-0003-2716-1990

I. О. Соколовсъка,

к. т. н., дочент, дочент кафедри індустрії гостинності та сталого розвитку,

Таврійський начіональний університет імені В. І. Вернадсъкого

ORCID ID: 0000-0003-4661-6751

\section{ІНСТРУМЕНТИ ЗАБЕЗПЕЧЕННЯ КОНКУРЕНТОСПРОМОЖНОСТІ САНАТОРНО- КУРОРТНИХ ЗАКАААІВ ГОСТИННОСТІ В УKPAÏHI}

\author{
H. Tarasiuk, \\ Doctor of Economic Sciences, Professor, Dean of the Faculty of Business and Service, \\ Zhytomyr Polytechnic State University \\ A. Chahaida, \\ PhD in Technical Sciences, Associate Professor, Associate Professor of the Department of Tourism, \\ Hotel and Restaurant Business, Zhytomyr Polytechnic State University \\ I. Petrovska, \\ PhD in Economics, Associate Professor, Senior Researcher, Head of the Department \\ of Hospitality Industry and Sustainable Development, V.I. Vernadsky Taurida National University \\ I. Sokolovska, \\ PhD in Technical Sciences, Associate Professor, Associate Professor of the Department of Hospitality \\ Industry and Sustainable Development, V.I. Vernadsky Taurida National University
}

\section{TOOLS FOR ENSURING THE COMPETITIVENESS OF SANATORIUMS IN UKRAINE}

\footnotetext{
Забезпечення збереження та розвитку дюдського потенціалу великою частою залежить від стану індустрї гостинності, а саме санаторно-курортні та оздоровчі закАади. На Сьогодні ринки послуг цієї сфери в Украйні розвиваються диспропорційно, а мережа закАадів скорочується. Такі тенденції вимагають переглядУ загального ПідходУ до розвитку цієї сфери: залучення фахівців із Створення нових та удосконалення існуючих продуктів та послуг, передусім використання останніх наукових, осягнень. Рівень Смертності збільшується, Причиною цьому є П Поблеми харчування через Умови життя, і Проблеми $з$ Системою охорони Здоров'я. Тривалий та глибокий дефіцит мікронутрієнтів, особливо небезпечний тим, що значний час не проявляеться кАінічно, споживання продуктів Ультрапереробки швидко витісняє із споживчого кошику необроблені або мінімально оброблені продукти та свіжоприготовані страви. Неінфекційні захворювання є серйозною проблемою глобальної громадської охорони здоров'я, проблема інтоксикації тісно пов 'язана із загальним станом здоров'я Аюдини. Програми "детоксикації" можуть Пропонуватись У
} 


\section{ЕКОНОМІЧНА НАУКА}

медичних центрах або бути частиною Аікування та вкАючати якийсь один процес або декілька різних підходів. Аікувально-оздоровчі закАади гостинності мають запропонувати потенційним Споживачам СУчасні послуги: програм діагностики та оздоровлення, пропозиції поліпшення харчування, шеllnеss-послуги тощо.

An important element in ensuring the preservation and development of human potential are sanatoriums and health facilities, but the regional markets for services in this area in Ukraine are developing disproportionately and the network of facilities is declining. Negative trends require the involvement of specialists to create new and improve existing products of the spa sector, change the attitude of medical staff to consumers of services and the development of rehabilitation and treatment programs based on the latest scientific advances. Reducing mortality and increasing life expectancy is primarily the result of improved living conditions through increased well-being, access to better nutrition, health care and sanitation. A common problem inherent in the nutrition of the population of all countries of the world is the insufficient intake of micronutrients. Prolonged and profound micronutrient deficiency, especially dangerous because it does not manifest itself clinically for a long time and leads to serious illness and can be fatal. Non-communicable diseases are a serious public health problem, especially in Europe. A separate problem is intoxication of the body: toxins that come from the outside or are produced inside, and their accumulation that can be harmful to health. Toxins are primarily eliminated from the body through healthy kidneys, liver and colon, but if there is poisoning by potent toxins, then there are scientifically sound procedures and medical programs to detoxify the body. In general, 'detox' programs can be advertised for commercial purposes, offered in medical centers, or be part of treatment and involve one process or several different approaches, which include: fasting; consumption of only clearly defined products; use of medicinal herbs; consumption of only natural juices; bowel cleansing using hydrotherapy; use of food additives; use of sauna. Recent studies confirm the exponentialgrowth in the production and consumption of ultra-processed products, which are rapidly displacing unprocessed or minimally processed products and freshly prepared foods from the consumer basket. These trends are already having a negative impact on the health of people and hospitality institutions should offer potential consumers modern areas of medical services, ranging from diagnostic and rehabilitation programs to a variety of wellness services.

Ключові слова: інтоксикачія, продукти ультрапереробки, санаторно-курортні заклади, оздоровлення, wellness-nослуги.

Key words: intoxication, ultra-processed products, sanatoriums, bealth improvement, wellness services.

\section{ПОСТАНОВКА ПРОБЛЕМИ}

Згідно з останнім звітом UNWTO "Барометр світового туризму", колапс у сфері міжнародних подорожей спричинив втрату експортних доходів у розмірі 1,3 трильйона доларів США, що в понад 11 разів перевищує втрати, зафіксовані під час глобальної економічної кризи 2009 року, при цьому розширені сценарії на 2021-2024 роки показують, що для повернення міжнародного туризму до рівня 2019 року може знадобитися від двох 3 половиною до чотирьох років [1]. Важливим елементом забезпечення збереження та розвитку людського потенціалу є санаторно-курортні та оздоровчі заклади, але регіональні ринки послуг цієї сфери в Україні розвиваються диспропорційно, а мережа закладів тенденційно скорочується [2, с. 173-177]. Сучасний стан матеріально-технічної бази санаторно-лікувальних закладів України залишається на рівні, далекому від світових стандартів і тому ключовим питанням органів державного управління та місцевого самоврядування варто вважати налагодження конкурентоспроможного ринку рекреаційних послуг шляхом модернізації існуючих закладів, підвищення якості життя населення, що забезпечить зростання їхньої купівельної спроможності [3, c. 26-30]. Негативні тенденції вимагають залучення фахівців із створення нових та удосконалення існуючих продуктів санаторно-курортної сфери, зміну ставлення медичного персоналу до споживачів послуг та розроблення програм оздоровлення і лікування на основі останніх наукових досягнень.

\section{АНАЛІЗ ОСТАННІХ ДОСЛІДЖЕНЬ І ПУБЛІКАЦІЙ}

Особливості розвитку лікувально-оздоровчих закладів гостинності в Україні та регулювання економічних процесів їх функціонування відображені у наукових працях Н.I. Ведмідь [4; 5], Н.М. Влащенко [6], Ю.М. Воробйова [7, с. 46-49], П.І. Гамана [8], О.В. Чайковської [9]. В наукових роботах розглянуто і запропоновано шляхи налагодження ефективного управління та удосконалення сервісної діяльності санаторно-курортних закладів з метою досягнення максимальних економічних показників та соціального результату. Однак постійні зміни уподобань споживачів та їх бажання досягти оптимального духовного і фізичного стану обумовлює необхідність подальшого дослідження можливих шляхів забезпечення конкурентоспроможності санаторно-курортних та лікувальних закладів.

\section{META CTATTI}

Метою дослідження є аналіз стану ринку послуг, що надають санаторно-курортні і лікувальні заклади та виявлення сучасних тенденцій розвитку цієї сфери з метою залучення нових споживачів.

\section{ВИКЛАД ОСНОВНОГО MATEPIAЛY}

Негативні тенденції у сфері санаторно-курортного господарства України, через хронічне недофінансуван- 
Таблиця 1. Санаторно-курортні та оздоровчі заклади України

\begin{tabular}{|c|l|l|l|l|}
\hline \multirow{2}{*}{ рік } & \multicolumn{2}{|c|}{$\begin{array}{c}\text { Санаторії та пансіонати } \\
\text { з лікуванням }\end{array}$} & \multicolumn{2}{|c|}{$\begin{array}{c}\text { Санаторії- } \\
\text { профілакторії }\end{array}$} \\
\cline { 2 - 5 } & усього & $\begin{array}{c}\text { у них ліжок, } \\
\text { тис. }\end{array}$ & усього & $\begin{array}{c}\text { у них } \\
\text { ліжок, тис. }\end{array}$ \\
\hline 2014 & 320 & 79 & 118 & 17 \\
\hline 2015 & 309 & 78 & 79 & 12 \\
\hline 2016 & 291 & 70 & 63 & 10 \\
\hline 2017 & 284 & 71 & 55 & 10 \\
\hline
\end{tabular}

Ажерело: [12].

Таблиця 2. Дитячі заклади оздоровлення та відпочинку

\begin{tabular}{|l|l|l|l|l|}
\hline \multirow{2}{*}{ рік } & \multicolumn{2}{|c|}{$\begin{array}{c}\text { Загальна кількість } \\
\text { закладів }\end{array}$} & \multicolumn{2}{|c|}{ Заклади оздоровлення } \\
\cline { 2 - 5 } & усього & $\begin{array}{c}\text { у них } \\
\text { ліжок, тис. }\end{array}$ & усього & $\begin{array}{c}\text { у них ліжок, } \\
\text { тис. }\end{array}$ \\
\hline 2014 & 13977 & 126 & 452 & 112 \\
\hline 2015 & 9743 & 113 & 333 & 81 \\
\hline 2016 & 9669 & 112 & 316 & 79 \\
\hline 2017 & 9745 & 106 & 299 & 73 \\
\hline 2018 & 9328 & 94 & 244 & 63 \\
\hline 2019 & 8808 & 98 & 241 & 63 \\
\hline
\end{tabular}

Ажерело: [13].

ня та втрату споживачів послуг, призвели до погіршення матеріально-технічної бази, відставання у розвитку лікувально-оздоровчого туризму. Відірваність від маркетингових інструментів просування продукту санаторно-курортного господарства поглиблює, 3 однієї сторони, економічні проблеми в операційній діяльності закладів, а 3 іншої сторони, втрату потенційних комерційних споживачів, що можуть бути залучені через мережу підприємств туристичної сфери та забезпечувати підприємства доходами. Нинішня структура санаторнокурортної сфери пов'язана із системою фінансування підприємств та потребує заходів законотворчого характеру та створенням умов для залучення інвестицій $[10$, c. $37-45]$.
Зменшення кількості санаторно-курортних і оздоровчих закладів пов'язано із скороченням державного фінансування соціальних гарантій різних верств населення, зниженням можливостей профспілкових організацій в оздоровленні працівників та проблемами із відповідністю пропозицій закладів більш високим вимогам сучасних споживачів (табл. 1 і 2). На відміну від послуг курортного лікування, які створювалися в державному секторі економіки послуг охорони здоров'я, інноваційна пропозиція SPA\&Wellness розвивається в приватному секторі курортно-рекреаційної сфери. Wellness став однією із найбільш ефективних форм рекреації, що забезпечує концентрацію життєвих сил людини, розширює можливості відтворення здоров'я нації, а найбільш успішними в освоєнні "філософії доброго самопочуття" і перетворення ㄲï на професійну основу інноваційного підприємництва виявились оздоровниці і готельні комплекси. Основні світові тенденції інноваційного розвитку курортно-рекреаційних комплексів ще недостатньо закріпилися на ринку послуг України, і тому wellness індустрія розвивається не системно та має фрагментарно-точковий характер $[11$, с. 186-200]. Ще однією проблемою у розвитку wellness-індустрії є те, що попит, стосовно певного виду послуг, може суттєво залежати від цінової пропозиції і важко спрогнозувати довготривалість уподобань зі сторони потенційних споживачів.

Зниження рівня смертності і збільшення тривалості життя, передусім, є результатом поліпшення умов життя за рахунок зростання добробуту, доступу до кращого харчування, охорони здоров'я та санітарії, а також політичної стабільності в країні. Екологічна ситуація, особисте ставлення до власного здоров'я та умови праці значною мірою впливають на самопочуття людини, тому ефективна система профілактики, лікування і реабілітації в санаторно-курортних умовах дозволяють не лише поліпшити стан здоров'я, а і підвищити продуктивність праці та стати необхідною складовою зростання економіки країни. Фонд соціального страхування України співпрацює із значною кількістю санаторнокурортних закладів, що надають послуги із лікуванні органів травлення (табл. 3).

Таблиця 3. Санаторно-курортні заклади, з якими співпрацює Фонд соціального страхування України

\begin{tabular}{|c|c|c|c|c|c|}
\hline & \multirow{3}{*}{$\begin{array}{c}\text { Регіон (область) } \\
\text { розташування } \\
\text { санаторно- } \\
\text { курортного закладу }\end{array}$} & \multicolumn{4}{|c|}{ Кількість санаторно-курортних закладів } \\
\hline & & \multirow{2}{*}{ всього } & \multicolumn{3}{|c|}{$\begin{array}{c}\text { в тому числі за профілем лікування } \\
\text { захворювань: } \\
\end{array}$} \\
\hline & & & $\begin{array}{c}\text { органів } \\
\text { травлення }\end{array}$ & $\begin{array}{l}\text { ендокринної } \\
\text { системи }\end{array}$ & $\begin{array}{l}\text { нервової } \\
\text { системи }\end{array}$ \\
\hline 1 & Вінницька & 1 & 1 & 1 & 1 \\
\hline 2 & Волинська & 2 & 2 & 1 & 1 \\
\hline 3 & Дніпропетровська & 3 & 3 & 1 & 3 \\
\hline 4 & Донецька & 1 & - & - & 1 \\
\hline 5 & Житомирська & 1 & 1 & - & 1 \\
\hline 6 & Закарпатська & 7 & 5 & 5 & 2 \\
\hline 7 & Запорізька & 7 & 7 & 5 & 6 \\
\hline 8 & Івано-Франківська & 2 & 1 & - & 1 \\
\hline 9 & Київська (м. Київ) & 6 & 2 & 1 & 5 \\
\hline 10 & Кіровоградська & 1 & - & - & 1 \\
\hline 11 & Луганська & 1 & 1 & 1 & 1 \\
\hline 12 & Львівська & 13 & 11 & 11 & 12 \\
\hline 13 & Миколаївська & 2 & 1 & - & 2 \\
\hline 14 & Одеська & 11 & 4 & 5 & 10 \\
\hline 15 & Полтавська & 4 & 4 & - & 1 \\
\hline 16 & Рівненська & 1 & 1 & - & 1 \\
\hline 17 & Сумська & 1 & 1 & 1 & 1 \\
\hline 18 & Тернопільська & 2 & 1 & 1 & 2 \\
\hline 19 & Харківська & 2 & 1 & 1 & 2 \\
\hline 20 & Херсонська & 3 & - & 2 & 3 \\
\hline 21 & Хмельницька & 2 & 2 & 1 & - \\
\hline 22 & Черкаська & 1 & 1 & 1 & 1 \\
\hline \multirow[t]{2}{*}{23} & Чернігівська & 1 & 1 & 1 & 1 \\
\hline & Разом: & 75 & 51 & 39 & 59 \\
\hline
\end{tabular}




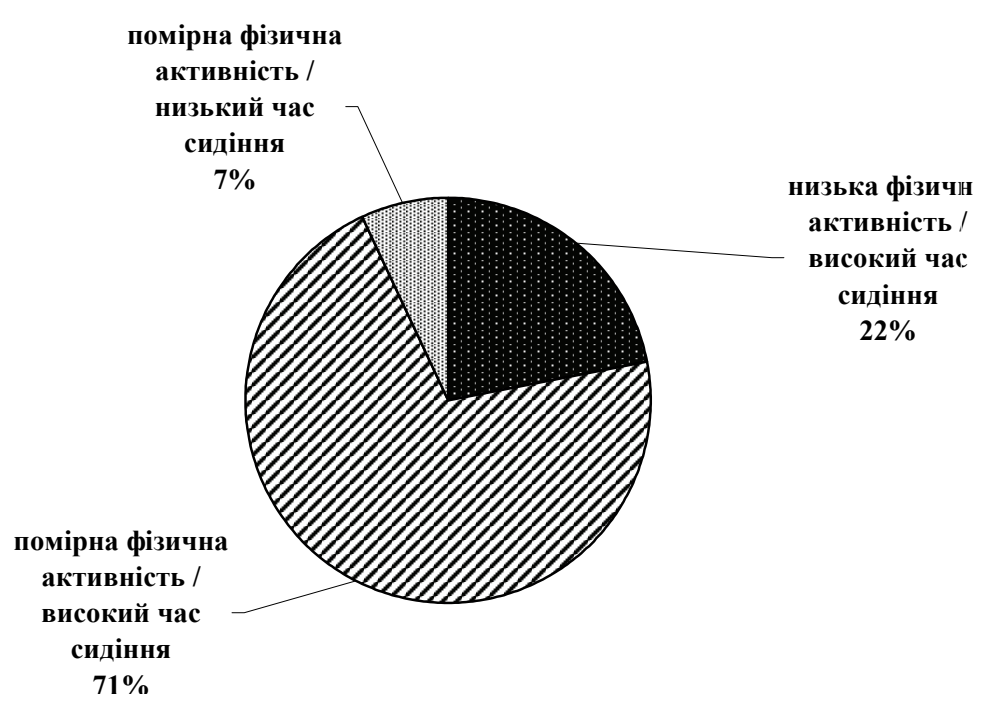

\section{Рис. 1. Діаграма розподілу респондентів за категоріями співвідношення фізичної активності / часу сидіння}

Останнє десятиріччя характеризується зростанням попиту на лікувальний туризм, що пов'язано, з однієї сторони, із погіршенням стану здоров'я населення, а 3 другої - із зростанням фінансових можливостей. В свою чергу стан здоров'я людини значною мірою залежить від харчування, що забезпечує не лише поповнення енерговитрат, а іє джерелом побудови клітин і синтезу регуляторів обмінних процесів. Загальною проблемою, що притаманна для харчування населення усіх без винятку країн світу, є недостатнє надходження з їжею мікронутрієнтів. Тривалий та глибокий дефіцит мікронутрієнтів, так званий "прихований голод", особливо небезпечний тим, що значний час не проявляється клінічно і призводить до тяжких захворювань та може бути причиною смерті [15, с. 63-68].

У 1980 році Міністерство сільського господарства разом із Міністерством охорони здоров'я та соціальних служб США вперше опублікували дослідження "Харчування і ваше здоров'я: рекомендації по харчуванню для американців", в якому було описано сім принципів здорового харчування, покликаних допомогти здоровим людям у щоденному виборі продуктів харчування. Зміст рекомендацій оновлюється кожні 5 років і опубліковані у грудні 2020 року дослідження свідчать про те, що хронічні захворювання, пов'язані з дієтою, являють собою серйозну проблему суспільної охорони здоров'я, адже $60 \%$ дорослих американців страждають на одне або декілька хронічних захворювань, пов'язаних із дієтою. Статистичні дані про стан здоров'я мешканців США фіксують, що близько 74\% дорослих та 40\% дітей і підлітків мають надлишкову вагу або ожиріння, більше $11 \%$ дорослих $\mathrm{i}$ $7 \%$ дітей та підлітків мають високий загальний рівень холестерину, а близько $45 \%$ дорослого населення США страждає на гіпертонію і серцево-судинні хвороби посідають перше місце серед причин смертності. Типові режими харчування, які нині використовуються багатьма в Сполучених Штатах, не збігаються з дієтичними рекомендаціями і індекс здорового харчування (показник якості дієти, який використовують для оцінки дотримання дієтичних рекомендації за шкалою від 0 до 100) хоч і незначно покращився за останні роки, але для вікової групи $14 . .18$ років складає 51 , для вікової групи $19 . . .30$ років 56, для вікової групи $31 \ldots 59$ років - 59, для вікової групи $60+-63$. При цьому $90 \%$ жінок і $97 \%$ чоловіків не дотримуються рекомендованої кількості споживання харчових волокон; 75\% американців традиційно споживають мало овочів та фруктів; 63\% - перевищують дозволені ліміти на доданий цукор; від 70 до $75 \%$ їдять більше, ніж рекомендовано, насичених жирів; 90\% - перевищують норми щодо споживання солі, що вказує на наявність значних можливостей для покращення харчування [16].
Аля зниження ризику неінфекційних захворювань, вкдючаючи гіпертонію, серцево-судинні захворювання та інсульт, пов'язаних із високим споживанням $\mathrm{NaCl}$, дослідниками розглядається кілька стратегій зниження вмісту солі в харчових продуктах. Аоведено, що сприйняття високої солоності корелює із високою швидкістю розчинення солі, на що впливає морфологія кристалів. Некубічні і агломеровані кристали, такі як кошерна і мальдонська солі, розчинялися швидше (швидкість розчинення в 3,8 рази вище) і проявляють максимальну солоність (до 17\% більше) в більш короткі терміни (до 40\% менше) [17, с. 676-679].

Аналіз більшості відомих дієт і рекомендацій по харчуванню створює неоднозначну уяву про базові вимоги до продуктів та черговості їх споживання, а спростування і критика конкурентів лише ще більше дезорієнтують потенційних клієнтів. Окрім того, замість позитивного ефекту сучасні рекомендації по здоровому способу життя можуть призвести до негативного результату та розладів харчової поведінки при використанні дієт, що радикально відрізняється від навколишньої культури і звичок харчування [18, с. $72-75]$. Ряд досліджень вказує на те, що більшість людей обирають їжу 3 більшою енергетичною цінністю і значним розміром порції, оскільки очікуване насичення відіграє при цьому ключову роль [19, с. 1885-1889]. Нині переїдання є світовою проблемою, і сукупні дані показують, що стрес викликає надмірне прагнення до смачної їжі. За класичною інтерпретацією надмірне переїдання - це спроба зменшити неприємне почуття, пов'язане з реакцією на стрес, за рахунок гедоністичних властивостей дуже смачної їжі. Aле стресовий стан викликає поведінку, пов'язану з пошуком їжі, незалежно від того, чи виникають позитивні емоції під час споживання, чи ні [20, с. 209-213].

Неінфекційні захворювання є серйозною проблемою глобальної громадської охорони здоров'я, що особливо актуально в Європі, де вони викликають $89 \%$ смертей і $84 \%$ років, прожитих з інвалідністю. Перше загальнонаціональне дослідження STEPS від Всесвітньої організації охорони здоров'я в Україні, виявило дуже високу поширеність неінфекційних захворювань і їх факторів ризику, включаючи високе споживання тютюну і алкоголю, дуже високе споживання солі та низьке споживання фруктів і овочів. Попри відносно низький рівень показнику нестачі фізичної активності, в країні має значне поширення надмірна вага і ожиріння громадян [21]. Відомо, що помірні та високо інтенсивні фізичні навантаження $є$ корисними для здоров'я, але не менш важливим показником оцінки загального стану є кількість часу, що люди проводять сидячи вдома, в офісі 
або у вільний час. Аані, отримані від респондентів віком від 18 до 29 років (32\% юнаків і 68\% дівчат), щодо загальної фізичної активності та загального часу сидіння оцінювались за допомогою міжнародного опитувальника з фізичної активності (IPAQ). Високий показник сидіння визначався часом у 240 та більше хвилин на день, а фізична активність визначалась за трьома рівнями: низьким, помірним та високим. Серед усіх респондентів не виявилось жодного, хто відповідав би критеріям високого рівня фізичної активності, а розподіл анкет за співвідношенням фізичної активності/ показника сидіння відображено на рисунку 1. Отримані дані свідчать про те, що незважаючи на значний відсоток респондентів із помірною (достатньою) фізичною активністю, абсолютна більшість молоді має високий показник щодо часу сидіння.

Аані анкетування щодо режиму харчування в $\mathrm{V}_{\mathrm{K}}$ раїні свідчать про те, що $37,5 \%$ молодих респондентів дотримується меншої кількості прийомів їжі, які характеризуються нерегулярністю, при цьому більшість раціону складають вироби з високим вмістом вуглеводів і незначна частина овочів та фруктів. Значний час, що проводить молодь за комп'ютером у соціальних мережах або за відеоіграми, має негативний вплив на стан здоров'я.

Аослідження взаємозв'язку між емоційним станом і споживанням їжі призвело до появи ряду методів вимірювання емоцій, які сильно розрізняються за своїм явним або неявним підходом до вимірювання та за ступенем усвідомлення з боку учасників експерименту. Ці методи є суб'єктивними і існують сумніви щодо незалежності їх результатів від традиційних вимірювань (симпатї̈, бажання і доречності), адже вони не дають відповіді на питання про специфіку емоційного змісту, а також чітко не регламентують час застосування (до, під час або в різні моменти після споживання їжі) [22, c. $183-189]$.

1 квітня 2016 року Генеральна Асамблея ООН проголосила Аесятиліття харчування, яке триватиме з 2016 по 2025 рік у рамках ініціативи ООН, адже на сьогодні майже 800 мільйонів людей хронічно недоїдають, а понад два мільярди - страждають від дефіциту поживних мікроелементів. Ця резолюція визнає, що поліпшення продовольчої безпеки та харчування мають визначальне значення для сталого розвитку і для досягнення усього Порядку денного на період до 2030 року [23]. На підтримку ініціатив ООН у вересні 2016 року Глобальна група експертів по сільському господарству і продовольчим системам для харчування, опублікувала свій звіт, який прогнозує різке погіршення ситуація протягом наступних 20 років, оскільки потужні рушійні зміни, пов'язані із зростанням населення, змінами клімату та урбанізацією поєднаються із реорганізацією продовольчих систем. Згідно із оцінками, до 2030 року кількість людей 3 надмірною вагою і ожирінням збільшиться 3 1,33 мільярда у 2005 році до 3,28 мільярда, що складатиме близько однієї третини прогнозованого населення світу. Це серйозна проблема, оскільки на сьогодні в жодній країні не вдалося зупинити зростання ожиріння і у цьому контексті особливу увагу має бути приділено виробництву та споживанню продуктів харчування і напоїв, які зазнали ультрапереробки [24]. Найважливішим фактором, коли мова йде про харчові продукти, харчування та громадське здоров'я, $є$ не поживні речовини і не самі продукти, а більшою мірою те, якій переробці продукти підлягали, тобто характер, масштаб і цілі обробки, а також що відбувається 3 харчовими продуктами в результаті цієї обробки [25, с. 729-731].

Класифікація NOVA групує харчові продукти за характером, ступенем і метою промислової обробки, яка включає в себе фізичні, біологічні та хімічні процеси, які використовуються після того, як продукти відокремили від природи, а також застосовуються перед вживанням або приготуванням страв. Ця класифікація дозво- ляє систематизувати переробку харчових продуктів на основі аналізу і оцінки характеру їі впливу на здоров'я людини, виявленим і виділеним типам та ефектам обробки, чітко визначеної термінології. За класифікацією NOVA харчові продукти розділено на 4 групи: 1 - необроблені або мінімально оброблені харчові продукти; 2 - оброблені кулінарні інгредієнти; 3 - оброблені харчові продукти; 4 - продукти харчування і напої, що пройшли ультраперероблення. Ао 4 групи відносять промислово виготовлені продукти, що зазвичай містить п'ять або більше інгредієнтів, які можуть використовуватись як у оброблених харчових продуктах, віднесених до 3 групи (цукор, масло, жир, сіль, антиоксиданти, стабілізатори і консерванти тощо), так і інгредієнти, що містяться тільки в ультраперероблених продуктах (до цих інгредієнтів відносять речовини, метою додавання яких $€$ імітація сенсорних якостей продуктів 1 групи або кулінарних приготувань із цих продуктів, або ж приховування небажаних сенсорних якостей кінцевого продукту). Харчові продукти 1 групи становлять невелику частину або навіть відсутні в ультраперероблених продуктах, зокрема йдеться про солодкі, жирні або солоні упаковані закуски, морозиво, цукровмісні напої, шоколад, кондитерські вироби, картоплю фрі, гамбургери і хот-доги, а також курячі та рибні нагетси [26, с. 29-36].

За даними дослідження у США основними джерелами доданих цукрів серед харчових продуктів були: безалкогольні напої $(17,1 \%$ від споживання доданих цукрів); морси $(13,9 \%)$; напої на основі молока $(4,6 \%)$; торти, печиво і пироги $(11,2 \%) ;$ хліб $(7,6 \%) ;$ десерти $(7,3 \%)$; солодкі закуски $(7,1 \%)$; сухі сніданки $(6,4 \%)$; морозиво $(5,9 \%)$ [27]. Аані 2020 року показують, що 57 відсотків середнього споживання калорій американцями припадає на продукти, які зазнали ультрапереробки. У цих продуктах відсутні поживні речовини, вони багаті хімічними добавками, маслом, цукром та сіллю, $\mathrm{i}$ на їх частку припадає 90 відсотків споживання доданого цукру в США [28, с. 447-454].

В організмі людини також $є$ токсини, які надходять ззовні або виробляються всередині, накопичення яких може бути шкідливими для здоров'я. При використанні слова "токсини" у людини виникає відчуття, що в організмі є щось дуже погане, від чого необхідно обов'язково позбутись, але здорові нирки, печінка та товста кишка самостійно повинні видаляти усі незначні токсичні речовини. Якщо відбулось отруєння сильнодіючими токсинами, то в такому випадку є науково обгрунтовані процедури і медичні програми з детоксикації організму. Загалом, програми "детоксикації" можуть рекламуватись в комерційних цілях, пропонуватись у медичних центрах або бути частиною лікування та включати якийсь один процес або декілька різних підходів, до яких відносяться: голодування; споживання тільки чітко визначених продуктів; застосування лікарських трав; споживання тільки натуральних соків; очищення кишківника з використанням гідротерапії; використання харчових добавок; використання сауни.

Одним із прикладів вдалого поєднання відпочинку оздоровлення є діяльність медичного центру Palace Merano - Espace Henri Chenot 5* (Італія), що працює за методикою Анрі Шено (Henri Chenot) [29; 30]. Ця методика, основною метою якої є очищення організму від шлаків та токсинів, заснована на дослідженні психофізичного старіння і його уповільненні та направлена на покращення самопочуття і формування корисних звичок харчування у пацієнтів. дика грунтується на декількох складових: режим харчування створюється індивідуального для кожного пацієнта на основі принципу помірності; виведенню токсинів сприяє велика кількість напоїв із лікарських трав; використання досвіду вчень китайської медицини при проведенні масажу енергетичних точок; СПАпроцедури. 


\section{ВИСНОВКИ}

Продовольчі системи і постачання змінюють масштаби і цілі обробки харчових продуктів, а супермаркети швидко витісняють спеціалізованих дрібних продавців. Продукти ультрапереробки $є$ портативними, зручними і доступними та спонукають до нових харчових звичок (пропуск основних прийомів їжі або прийом їжі під час інших справ). Останні дослідження підтверджують експоненціальне зростання виробництва і споживання продуктів ультрапереробки, що розроблені як готові до вживання або лише до остаточного нагрівання перед споживанням, і ці продукти швидко витісняють із споживчого кошику необроблені або мінімально оброблені продукти та свіжоприготовані страви. Ці тенденції вже мають негативний вплив на стан здоров'я людей і лікувальнооздоровчі заклади гостинності мають запропонувати потенційним споживачам сучасні напрями медичних послуг, починаючи від програм діагностики та оздоровлення і до різноманітних пропозицій Wellness-послуг.

\section{$\Lambda$ ітература:}

1. UNWTO World Tourism Barometer [Електронний peсурс]. - Режим доступу: https://www.unwto.org/ unwto-world-tourism-barometer-data

2. Карий, O.I. Санаторно-курортні і оздоровчі заклади в Україні: видова характеристика, регіональна специфіка та динаміка розвитку / O.I. Карий, А.I. Гальків, А.В. Галаз // Науковий вісник Полісся. 2018. № 2 (14), Ч. 1. C. $172-178$.

3. Холявка, В. 3. Сучасні аспекти, фактори впливу i перспективи розвитку медичного та лікувально-оздоровчого туризму в Україні / В.З. Холявка, Х.С. Аешко, О.М. Мочульська, А.О. Кухтій // Вісник соціальної гігієни та організації охорони здоров'я України. 2019. № 1 (79). С.25-33.

4. Ведмідь Н.І. Санаторно-курортний комплекс: сервісне управління: монографія / H.І. Ведмідь. - Київ: Київ. нац. торг.-екон. ун-т, 2013. - 536 с.

5. Ведмідь Н.I. Сервісне управління підприємствами курортно-рекреаційної сфери: автореф. дис.... А-ра екон. наук: 08.00.04 - економіка та управління підприємствами / Н.I. Ведмідь. - Київ: Київ. нац. торг.-екон. ун-т, 2014. - 40 с.

6. Влащенко Н.М. Розвиток санаторно-курортного комплексу регіону: соціально-економічний аспект: монографія / H.M. Влащенко; Харк. нац. акад. міськ. госпва. - Харків: ХНАМГ, 2012. - 151 с.

7. Воробйов Ю.М. Фінансове забезпечення розвитку санаторно-курортно-рекреаційних закладів / Ю.М. Воробйов // Науковий вісник: Фінанси, банки, інвестиції. 2012. - № 3. - C. 46-49.

8. Гаман П.І. Розвиток рекреаційної сфери Карпатського регіону України: теорія та практика державного регулювання: монографія / П.І. Гаман; Рада по вивч. продукт. сил України НАН України. - Аонецьк: Юго-Восток, $\Lambda$ та, 2008. - 306 с.

9. Чайковська О.В. Фінансове забезпечення розвитку санаторно-курортних закладів: монографія / О.В. Чайковська, Г.П. Костенко; Аонец. нац. ун-т економіки і торгівлі ім. Михайла Туган-Барановського. Аонецьк: АонНУЕТ, 2013. - 260 с.

10. Ярьоменко, С.Г. Тенденції розвитку санаторнокурортного господарства Одеської області / С.Г. Ярьоменко, Н.С. Мартинова, Р.С. Козловський // Причорноморські економічні студії. 2020. Вип. 55. Ч. 2. С. 37-45.

11. Гуменюк В.В. Аержавне регулювання курортнорекреаційної сфери: монографія / В.В. Гуменюк. - Київ: Київ. нац. торг.-екон. ун-т, 2016. - 372 с.

12. Санаторно-курортні та оздоровчі заклади (1990-2017) [Електронний ресурс]. - Режим доступу: http://www.ukrstat.gov.ua/operativ/operativ2007/tyr/ tyr_u/skz2006_u.htm

13. Аитячі заклади оздоровлення та відпочинку, які працювали влітку (2000-2019) [Електронний ресурс]. -
Режим доступу: http://www.ukrstat.gov.ua/operativ/ operativ2019/tyr/dzov/dzov_u.htm

14. Інформаційний перелік санаторно-курортних закладів у розрізі регіонів, місцерозташування та профілів санаторно-курортного лікування, за якими надаються санаторно-курортні послуги потерпілим (особам з інвалідністю) внаслідок нещасного випадку на виробництві та професійного захворювання [Електронний ресурс]. - Режим доступу: http://www.fssu.gov.ua/ fse/control/main/uk/publish/article/962596

15. Корзун В.Н. Теоретичні основи створення та вживання продуктів спеціального призначення / В.Н. Корзун // Аовкілля та здоров'я. - 2009. - № 1. - С. 63-68.

16. Dietary Guidelines for Americans 2020-2025. Make Every Bite Count With the Dietary Guidelines [Електронний ресурс]. - Режим доступу: https://www.dietaryguidelines.gov/sites/default/files/2020-12/Dietary_Guidelines_for_Americans_2020-2025.pdf

17. Quilaqueo M., Düizer L., Aguilera J.M. The morphology of salt crystals affects the perception of saltiness. Food Research International. 2015. Vol. 76. Part 3. P. $675-681$.

18. Тарасюк Г.М. Розвиток wellness-індустрії в закладах гостинності на основі використання потенціалу інтелектуальних послуг / Г.М. Тарасюк, А.О. Чагайда, I.O. Соколовська // Вчені записки ТНУ імені B.I. Вернадського. Серія: Економіка і управління. 2020. Т. 31 (70). № 5 . C. $71-76$.

19. Brunstrom J.M., Rogers P.J. How Many Calories Are on Our Plate? Expected Fullness, Not Liking, Determines Mealsize Selection. Obesity. 2009. Vol.17. Is.10. P. 18841890.

20. Pool E., Delplanque S., Coppin G., Sander D. Is comfort food really comforting? Mechanisms underlying stress-induced eating. Food Research International. 2015. Vol. 76. Part 2. P.207-215.

21. STEPS survey reveals high prevalence of noncommunicable disease risk factors in Ukraine [Електронний ресурс]. - Режим доступу: https://www.euro.who.int/en/countries/ukraine/news/news/2020/11/stepssurvey-reveals-high-prevalence-of-noncommunicabledisease-risk-factors-in-ukraine

22. Koster E.P., Mojet J. From mood to food and from food to mood: A psychological perspective on the measurement of food-related emotions in consumer research. Food Research International. 2015. Vol. 76. Part 2. P. $180-191$.

23. Food and Agriculture Organization of the United Nations (2016) UN General Assembly proclaims Decade of Action on Nutrition. http://www.fao.or/ew/tor//te/0897/ code/

24. Global Panel on Agriculture and Food Systems for Nutrition (2016) Food Systems and Diets: Facing the Challenges of the 21st Century. London: Global Panel; available at http://glopan.or/ite/efaul/ile/oresightReport.pdf

25. Monteiro C.A. Nutrition and health. The issue is not food, nor nutrients, so much as processing. Public Health Nutr. 2009 May;12(5):729-31. doi: 10.1017/ S1368980009005291

26. Monteiro C.A., Cannon G., Levy RB, Moubarac J.C., Jamie P., Martins A.P., Canella D. NOVA. The star shines bright. World Nutrition. January - March 2016; 7(1-3): P. 28-38.

27. Martinez Steele E., Baraldi L.G., Louzada M.L.D.C, et al. Ultra-processed foods and added sugars in the US diet: evidence from a nationally representative cross-sectional study. BMJ Open 2016; 6. doi: 10.1136/bmjopen-2015009892

28. Bonaccio M., Di Castelnuovo A., Costanzo S., De Curtis A., Persichillo M., Sofi F., Cerletti C., Donati M.B., de Gaetano G., Iacoviello L. Ultra-processed food consumption is associated with increased risk of all-cause and cardiovascular mortality in the Moli-sani Study. The 
American Journal of Clinical Nutrition, Vol. 113, Issue 2, February 2021, Pages 446-455. URL: https://doi.org/ $10.1093 / \mathrm{ajcn} / \mathrm{nqaa} 299$

29. Chenot H. Pure Health: The Secrets of Well-being and Harmony. London: Metro Books, 2011. 288 p.

30. Chenot H. Piu sani, piu giovani, piu magri. Milano: Sperling \& Kupfer, 2016. 172 p.

\section{References:}

1. World Tourism Organization (2021), "UNWTO World Tourism Barometer", available at: https:// www.unwto.org/unwto-world-tourism-barometer-data (Accessed 28 Jan 2021).

2. Kariy, O.I. Halkiv, L.I. and Halaz, L.V. (2018), "Sanatoriums and health facilities in Ukraine: species characteristics, regional specifics and dynamics of development", Naukovyi visnyk Polissia, vol. 2 (14), no. 1, pp. $172-178$.

3. Kholiavka, V.Z. Leshko, Kh.C. Mochulska, O.M. and Kukhtiy A.O.(2019), "Modern aspects, factors of influence and prospects of development of medical and medical and health tourism in Ukraine", Visnyk socialnoyi hihiyieny ta organizaciyi okhorony zdorovyia Ukrayiny, vol. 1 (79), pp. $25-33$.

4. Vedmid', N.I. (2013), Sanatorno-kurortnyj kompleks: servisne upravlinnia [Sanatorium-resort complex: service management], Kyiv National University of Trade and Economics, Kyiv, Ukraine.

5. Vedmid', N.I. (2014), "Service management of resort and recreational enterprises", Dr.Sc Thesis, Global economy, Kyiv National University of Trade and Economics, Kyiv, Ukraine.

6. Vlaschenko, N.M. (2012), Rozvytok sanatornokurortnoho kompleksu rehionu: sotsial'no-ekonomichnyj aspekt [Development of the sanatorium-resort complex of the region: socio-economic aspect], National Academy of Urban Economy in Kharkiv, Ukraine.

7. Vorobyiov, Yu.M. (2012), "Financial support for the development of sanatoriums and recreational facilities", Naukoviy visnik: Finansi, banki, investiciyi, vol. 3, pp. 46-49.

8. Haman, P.I., (2013), Rozvytok rekreatsijnoi sfery Karpats'koho rehionu Ukrainy: teoriia ta praktyka derzhavnoho rehuliuvannia [Development of the recreational sphere of the Carpathian region of Ukraine: theory and practice of state regulation], Rada po vyvch. produkt. syl Ukrainy NAN Ukrainy. Yuho-Vostok Ltd, Donets'k, Ukraine.

9. Chajkovs'ka, O.V. and Kostenko, H.P. (2013), Finansove zabezpechennia rozvytku sanatorno-kurortnykh zakladiv [Financial support for the development of sanatoriums], Mykhailo Tugan-Baranovsky Donetsk National University of Economics and Trade, Donets'k, Ukraine.

10. Jar'omenko, S.G. Martinova, N.S. and Kozlovs'kij, R.S. (2020), "Trends in the development of sanatorium and resort economy of Odessa region", Prichornomors'ki ekonomichni studiï, vol. 55, no. 2, pp. 37-45.

11. Humeniuk, V.V. (2016), Derzhavne rehuliuvannia kurortno-rekreatsijnoi sfery [State regulation of resort and recreational sphere], Kyiv National University of Trade and Economics, Kyiv, Ukraine.

12. State Statistics Service of Ukraine (2007), "Sanatoriums and health resorts (1990-2017)", available at: http:// www.ukrstat.gov.ua/operativ/operativ2007/tyr/tyr_u/ skz2006_u.htm (Accessed 28 Jan 2021).

13. State Statistics Service of Ukraine (2019), "Children's health and recreation facilities that worked in the summer (2000-2019)", available at: http://www.ukrstat.gov.ua/ operativ/operativ2019/tyr/dzov/dzov_u.htm (Accessed 28 Jan 2021).

14. Social insurance fund (2021), "Information list of sanatoriums in terms of regions, location and profiles of sanatorium treatment, which provide sanatorium services to victims (persons with disabilities) due to an accident at work and an occupational disease", available at: http:// wWw.fssu.gov.ua/fse/control/main/uk/publish/article/ 962596 (Accessed 12.01.2021).

15. Korzun, V. N. (2009), "Theoretical bases of creation and use of products of special purpose", Dovkillja ta zdorov'ja, vol. 1, pp. 63-68.

16. Dietary Guidelines for Americans (2020), "Dietary Guidelines for Americans 2020 - 2025. Make Every Bite Count With the Dietary Guidelines", available at: https:// www.dietaryguidelines.gov/sites/default/files/2020-12/ Dietary_Guidelines for_Americans_2020-2025.pdf (Accessed 28 Jan 2021).

17. Quilaqueo, M.Duizer, L. and Aguilera, J.M. (2015), "The morphology of salt crystals affects the perception of saltiness", Food Research International, vol. 76, no. 3, pp. $675-681$.

18. Tarasjuk, G.M. (2020), "Development of the wellness industry in hospitality institutions based on the use of the potential of intellectual services", V cheni zapiski TNU imeni V.I. Vernads'kogo. Serija: Ekonomika i upravlinnja, vol. 31 (70), no. 5, pp. $71-76$

19. Brunstrom, J.M. and Rogers, P.J. (2009), "How Many Calories Are on Our Plate? Expected Fullness, Not Liking, Determines Meal-size Selection", Obesity, vol. 17, no. 10, pp. $1884-1890$.

20. Pool, E. Delplanque, S. Coppin, G. and Sander, D. (2015), "Is comfort food really comforting? Mechanisms underlying stress-induced eating", Food Research International, vol. 76 , no. 2 , pp. $207-215$.

21. World Health Organization regional office for Europe (2020), "STEPS survey reveals high prevalence of noncommunicable disease risk factors in Ukraine", available at: https://www.euro.who.int/en/countries/ukraine/news/ news/2020/11/steps-survey-reveals-high-prevalence-ofnoncommunicable-disease-risk-factors-in-ukraine (Accessed 28 Jan 2021).

22. Koster, E.P. and Mojet, J. (2015), "From mood to food and from food to mood: A psychological perspective on the measurement of food-related emotions in consumer research", Food Research International, vol. 76, no. 2, pp. $180-191$.

23. United Nations (2016), "Resolution adopted by the General Assembly on 1 April 2016", available at: https:// www.un.org/en/ga/search/view_doc.asp?symbol=A/RES/ 70/259 (Accessed 28 Jan 2021).

24. Global Panel on Agriculture and Food Systems for Nutrition (2016), "Food Systems and Diets: Facing the Challenges of the 21st Century. London: Global Panel", available at: http://glopan.or/ite/efaul/ile/oresightReport.pdf (Accessed 28 Jan 2021).

25. Monteiro, C.A. (2009), "Nutrition and health. The issue is not food, nor nutrients, so much as processing", Public Health Nutr, vol. 12 (5), pp. 729-731. doi:10.1017) S1368980009005291

26. Monteiro, C.A. Cannon, G. Levy, R.B. Moubarac, J.C. Jamie, P. Martins, A.P. and Canella, D. N. (2016), "The star shines bright", World Nutrition, vol. 7 (1-3), pp. 28-38.

27. Martinez, S. E. Baraldi, L.G. and Louzada, M.L.D.C (2016), "Ultra-processed foods and added sugars in the US diet: evidence from a nationally representative crosssectional study", BMJ Open, vol. 6. doi: 10.1136/bmjopen2015-009892

28. Bonaccio, M. Di Castelnuovo, A. Costanzo, S. De Curtis, A. Persichillo, M. Sofi, F. Cerletti, C. Donati, M.B. de Gaetano, G and Iacoviello, L. (2021), "Ultra-processed food consumption is associated with increased risk of allcause and cardiovascular mortality in the Moli-sani Study", The American Journal of Clinical Nutrition, vol. 113, no. 2, pp. 446-455, https://doi.org/10.1093/ajcn/nqaa299

29. Chenot, H. (2011) Pure Health: The Secrets of Wellbeing and Harmony, Metro Books, London, UK.

30. Chenot, H. (2016), Piu sani, piu giovani, piu magri [Healthier, younger, leaner], Sperling \& Kupfer, Milano, Italy. Стаття надійила до редакиіï 04.03.2021 p. 